\title{
HUBUNGAN PARITAS DAN PENDIDIKAN IBU TERHADAP KEJADIAN PREEKLAMPSIA DI RSUD IDAMAN BANJARBARU
}

\author{
Rubiati Hipni \\ Dosen Poltekkes Kemenkes Banjarmasin \\ Email: rubiatihipni@yahoo.co.id
}

\begin{abstract}
ABSTRAK
Preeklampsia merupakan komplikasi medis dari kehamilan dan terjadi sekitar $5 \%-8 \%$ dari kehamilan yang menyebabkan tingginya morbiditas dan mortilitas pada ibu dan janin.

Tujuan Penelitian ini untuk mengetahui hubungan paritas dan pendidikan ibu terhadap kejadian preeklampsiadi RSUD Idaman Banjarbaru.

Metode yang digunakan adalah survei analitik dengan rancangan penelitian yang digunakan adalah case control, menggunakan teknik sampel purposive sampling, responden yang digunakan pada kasus adalah 100 orang ibu hamil dengan preeklampsia dan pada kontrol 100 orang ibu hamil normal, pengumpulan data ini dengan cara melihat rekam medik lalu dianalisis secara univariat dan bivariat dengan menggunakan analisis Rank Spearman Correlation.

Hasil penelitian ada hubungan yang signifikan antara paritas dengan kejadian preeklampsia $(\mathrm{p}=0,002)$, tidak ada hubungan yang signifikan pendidikan dengan kejadian preeklampsia $(p=0,121)$.

Penelitian ini dapat disimpulkan bahwa ada hubungan yang signifikan antara paritas dengan kejadian preeklampsia dan tidak ada hubungan yang signifikan antara pendidikan dengan kejadian preeklampsia.
\end{abstract}

Kata Kunci: Preeklampsia, Paritas, Pendidikan

\section{ABSTRAC}

Preeclampsia is a medical complication of pregnancy and occurs in about $5 \%-8 \%$ of pregnancies which cause high morbidity and mortility in the mother and fetus.

The purpose of this study was to determine the relationship of maternal parity and education to the incidence of preeclampsia in Idaman Banjarbaru Hospital.

Method: used is an analytical survey with the study design used was case control, using purposive sampling technique, respondents used in the case were 100 pregnant women with preeclampsia and in the control of 100 normal pregnant women, this data was collected by looking at the record Then the medical was analyzed by univariate and bivariate using Rank Spearman Correlation analysis.

The results of the study showed a significant relationship between parity and the incidence of preeclampsia $(p=0.002)$, there was no significant relationship between education and the incidence of preeclampsia $(p=0.121)$.

This study concluded that there was a significant relationship between parity and the incidence of preeclampsia and there was no significant relationship between education and the incidence of preeclampsia.

\section{Keywords: Preeclampsia; Parity; Education}

\section{PENDAHULUAN}

Preeklampsia merupakan komplikasi medis dari kehamilan dan terjadi sekitar $5 \%$ -
8\% dari kehamilan yang menyebabkan tingginya morbiditas dan mortilitas pada ibu dan janin (Shah et al, 2015; WHO, 2011). 
Tingginya angka kematian ibu (AKI) dan angka kematian bayi (AKB) merupakan salah satu indikator kesehatan. Di indonesia angka kematian ibu masih tinggi menurut Survey Demografi Kesehatan Indonesia (SDKI) pada tahun2012 mencapai 359/100.000 KH. Penyebab AKI meliputi perdarahan, hipertensi dalam kehamilan (HDK) dan infeksi. Berdasarkan The National High Blood Pressure Education Program Working Group on High Blood Pressure in Pregnancy (Lindheimeret al, 2009), menjelaskan bahwa klasifikasi hipertensi dalam kehamilan dibagi menjadi empat yaitu peeklampsia-eklampsia, hipertensi kronis, superimposed preeklampsia, dan hipertensi gestasional. Di negara berkembang angka kejadian preeklampsia 9-25\% dari seluruh kehamilan (Naljayan and Karumanchi, 2013; Huang et al.,2013; Polsani et al., 2013). Kematian ibu di Indonesia pada tahun 2011 hampir 30\% diakibatkan oleh preeklampsia (Ditjen Bina Gizi dan KIA Kemenkes RI, 2013).

Preeklampsia dipengaruhi oleh beberapa faktor yaitu primigravida atau $>10$ tahun sejak kelahiran terakhir, kehamilan pertama dengan pasangan baru, riwayat preeklampsia sebelumnya, riwayat keluarga dengan preeklampsia, kehamilan kembar, kondisi medis tertentu, adanya proteinuria, umur >40 tahun, obesitas, dan fertilitas in vivo (Bothamley et al, 2012).

Penyebab timbulnya preeklampsia pada ibu hamil belum diketahui secara pasti, tetapi pada umumnya disebabkan oleh vasospasme arteriola. Faktor-faktor lain yang diperkirakan akan mempengaruhi timbulnya preeklampsia antara lain: paritas, kehamilan ganda, hidramnion, mola hidatidosa, malnutrisi berat, usia ibu dan anemia, di negara-negara berkembang dihubungkan dengan masih rendahnya status sosial ekonomi dan tingkat pendidikan yang dimiliki kebanyakan masyarakat (Anik, Yulianingsih, 2009; Eka, 2014).

AKI di Kalimantan Selatan tahun 2014 sebanyak 120 orang yang disebabkan oleh perdarahan 33 orang $(27,5 \%)$, Pre Eklampsi/eklampsia 34 orang $(28,3 \%)$, infeksi 3 orang (2,5\%), abortus 1 orang (0.8\%), lainlain 49 orang $(40,8 \%)$. Tahun 2015 terjadi penurunan AKI sebanyak 89 orang yang disebabkan oleh perdarahan 27 orang $(30,3 \%)$, Pre Eklampsi/eklampsia 20 orang $(22,4 \%)$, infeksi 1 orang $(1,1 \%)$, gangguan peredaran darah 8 orang $(8,9 \%)$, gangguan metabolik 4 orang (4,4\%), lain-lain 29 orang (32,5\%) (Dinkes Prov.Kalsel, 2016).

Kejadian Pre Eklampsi di RSUD Idaman Banjarbaru cukup tinggi dan meningkat setiap tahun yakni pada tahun 2014 sebanyak 265 (4,4\%) dari 5961 persalinan dan meningkat pada tahun 2015 sebanyak 363 (7,6\%) dari 4776 persalinan.

RSUD Idaman Banjarbaru merupakan Rumah Sakit pendidikan dan mempunyai kerjasama yang baik, berdasarkan hasil studi pendahuluan tingginya angka kejadian pre eklampsi dan terjadi peningkatan setiap tahun yakni dari tahun 2014-2015 maka penulis tertarik untuk melakukan penelitian 
dengan judul "Hubungan Paritas Dan Pendidikan lbu Terhadap Kejadian Preeklampsia Di RSUD Idaman Banjarbaru".

\section{BAHAN DAN METODE}

Metode yang digunakan adalah survei analitik dengan rancangan penelitian yang digunakan adalah case control. Penelitian ini mengidentifikasi kejadian preeklampsi pada ibu bersalin untuk dijadikan kasus dan memilih ibu bersalin yang tidak preeklampsi untuk dijadikan kontrol kemudian melihat kebelakang untuk mengidentifikasi hubungan paritas dan pendidikan lbu dengan kejadian preeklampsia. Penelitian ini dilakukan di RSUD Idaman Banjarbaru dengan melihat rekam medik dari bulan Januari sampai Desember 2017.

Populasi dalam penelitian ini adalah seluruh ibu bersalin di RSUD Idaman pada tahun 2017 yaitu sebanyak 1976 orang. Teknik pengambilan sampel yang digunakan dalam penelitian ini adalah teknik purposive sampling yaitu teknik pengambilan sampel berdasarkan pertimbangan tertentu yang telah dibuat oleh peneliti, dengan kriteria inklusi yaitu, lbu bersalin yang mengalami preeklampsia/eklampsia untuk kasus memenuhi syarat untuk diteliti, lbu bersalin yang tidak mengalami preeklampsia/eklampsia untuk kontrol memenuhi syarat untuk diteliti dan data ada dibuku register tentang pasien lengkap sedangkan untuk kriteria ekslusi yaitu Ibu bersalin tidak memenuhi syarat untuk diteliti dan data ibu di buku register tidak lengkap.
Ibu bersalin tahun 2017 sebanyak 1976 ibu bersalin kemudian dipilih berdasarkan kriteria Inklusi dan eksklusi didapatkan ibu bersalin dengan preeklampsia sebanyak 100 orang, Jumlah sampel 1:1 yaitu 100 orang ibu bersalin yang mengalami preeklampsia/eklampsia dan 100 orang ibu bersalin yang tidak mengalami preeklampsia/normal yang diambil secara random/acak dari jumlah ibu bersalin yang tidak mengalami preeklampsia. Pengumpulan data ini dengan cara melihat rekam medik persalinan di RSUD Idaman Banjarbaru dari bulan Januari sampai Desember tahun 2017, data diolah kemudian dilakukan analisis univariat dan bivariat, dalam penelitian ini menggunakan uji Rank Spearman Correlation yang digunakan untuk mencari hubungan atau untuk menguji signifikansi hipotesis.

\section{HASIL DAN PEMBAHASAN}

\section{Analisis Univariat}

\section{a. Paritas}

Tabel 1. Distribusi frekuensi ibu bersalin berdasarkan Jumlah Persalinan di RSUD Idaman Banjarbaru Tahun 2017

\begin{tabular}{lcc}
\hline Paritas Ibu & Frekuensi & $\%$ \\
\hline $\begin{array}{l}\text { Jumlah persalinan } \\
\text { ibu 1 atau }>3\end{array}$ & 73 & 36.5 \\
$\begin{array}{l}\text { Jumlah persalinan } \\
\text { ibu 2-3 }\end{array}$ & 127 & 63.5 \\
\hline Total & $\mathbf{2 0 0}$ & $\mathbf{1 0 0 , 0}$ \\
\hline
\end{tabular}

Tabel 1 menunjukkan bahwa dari 200 ibu bersalin yang paling banyak melahirkan dengan jumlah persalinan 2-3 yaitu sebesar 127 orang (63,5\%). 
b. Pendidikan

Tabel 2. Distribusi frekuensi ibu bersalin berdasarkan Pendidikan lbu di RSUD Idaman Banjarbaru Tahun 2017

\begin{tabular}{lcc}
\hline Pendidikan lbu & Frekuensi & $\%$ \\
\hline $\begin{array}{l}\text { Rendah } \\
\text { (SD, SMP) }\end{array}$ & 79 & 39,5 \\
$\begin{array}{l}\text { Sedang } \\
\text { (SLTA) }\end{array}$ & 77 & 38,5 \\
$\begin{array}{l}\text { Tinggi } \\
\text { (Diploma, S1, S2) }\end{array}$ & 44 & 22,0 \\
\hline \multicolumn{1}{c}{ Total } & $\mathbf{2 0 0}$ & $\mathbf{1 0 0 , 0}$ \\
\hline
\end{tabular}

Tabel 2 menunjukan bahwa dari 200 ibu yang paling banyak memiliki pendidikan rendah yaitu sebesar 79 orang (79\%).

\section{Analisis Bivariat}

a. Hubungan antara paritas dengan kejadian preeklampsia

Tabel 3.Hubungan Paritas Dengan Kejadian Preeklampsia di RSUD Idaman Banjarbaru Tahun 2017.

\begin{tabular}{lcccccc}
\hline $\begin{array}{l}\text { Jumlah } \\
\text { persalinan }\end{array}$ & \multicolumn{2}{c}{ PEB } & \multicolumn{2}{c}{$\begin{array}{c}\text { Tidak } \\
\text { PEB }\end{array}$} & \multicolumn{2}{c}{ Total } \\
\cline { 2 - 7 } ibu & $\mathbf{n}$ & $\%$ & $\mathbf{n}$ & $\%$ & $\mathbf{n}$ & $\%$ \\
\hline $\begin{array}{l}\text { Jumlah } \\
\text { persalinan } \\
\text { ibu } 1 \text { atau } \\
>3\end{array}$ & 47 & 23.5 & 26 & 13 & 73 & 36,5 \\
$\begin{array}{l}\text { Jumlah } \\
\text { persalinan } \\
\text { ibu 2-3 }\end{array}$ & 53 & 26.5 & 74 & 37 & 127 & 63,5 \\
\hline Total & $\mathbf{1 0 0}$ & $\mathbf{5 0}$ & $\mathbf{1 0 0}$ & $\mathbf{5 0}$ & $\mathbf{2 0 0}$ & $\mathbf{1 0 0}$ \\
\hline
\end{tabular}

Tabel 3 menunjukkan bahwa dari 100 orang ibu yang mengalami PEB ada 47 $(23,5 \%)$ yang memiliki jumlah persalinan 1 atau >3dan $53(26,5 \%)$ yang memiliki jumlah persalinan 2-3. Sedangkan dari 100 ibu yang tidak mengalami PEB ada 26 $(13 \%)$ ibu yang memiliki jumlah persalinan
1 atau >3 dan 74 (37\%) yang memiliki jumlah persalinan 2-3.dari 200 ibu bersalin paling banyak jumlah persalinan ibu 2-3. Berdasarkan perhitungan kolerasi di atas, $\mathrm{n}$ menunjukan jumlah observasi sampel sebanyak 200, sedangkan tingginya kolerasi di tunjukan oleh angka 0,218. Besar kolerasi yang terjadi antara kedua variabel adalah 0,218 . Sedangkan angka sig. (2-tailed) adalah 0,002 berarti terdapat hubungan yang signifikan antara kedua variabel $(0,002<0,05)$.

Hasil penelitian ini sesuai dengan teori dimana wanita nullipara berisiko lima hingga sepuluh kali lipat lebih tinggi untuk menderita preeklampsi dibandingkan dengan wanita multipara. Jumlah persalinan ibu tinggi (>3) merupakan jumlah persalinan ibu berisiko terjadinya preeklampsi karena ibu dengan jumlah persalinan ibu tinggi mengalami penurunan fungsi sistem reproduksi (Lockwood et al, 2000).

Hasil penelitian ini sejalan dengan penelitian Hinda tahun 2016 dimana paritas berpengaruh terhadap kejadian preeklampsia, penelitian ini juga sejalan dengan penelitian Pratiwi tahun 2015 dimana terdapat hubungan yang signifikan antara paritas dengan kejadian preeklampsia pada ibu hamil di RSUD Wonosari yang menunjukkan bahwa ibu dengan paritas berisiko ( $<2$ atau $\geq 4$ ) 4,750 kali lebih berisiko mengalami preeklampsia dibandingkan dengan ibu dengan paritas tidak berisiko (2-3 kali) 
dimana pada primigravida/primipara terjadi gangguan imunologik (blocking antibodies) dimana produksi antibodi penghambat berkurang. Hal ini dapat menghambat invasi arteri spiralis ibu oleh trofoblas sampai batas tertentu hingga mengganggu fungsi placenta sehingga bisa menyebabkan preklampsia. Preeklampsia tidak hanya terjadi pada primigravida tapi juga pada grandemultipara memiliki risiko untuk mengalami eklampsia. Misalnya pada ibu hamil dan bersalin lebih dari tiga kali. Peregangan rahim yang berlebihan menyebabkan iskemia berlebihan yang dapat menyebabkan preeklampsia (Pratiwi, 2015).

Penelitian Novianti tahun 2015 mendapati dimana paritas ibu merupakan faktor resiko terjadinya preeklampsia. Paritas yang ideal adalah 2-3, ibu yang mempunyai anak >5 memiliki kecenderungan untuk mengalami masalah dalam kehamilannya.disebabkan karena pada kehamilan pertama pembentukan blocking antibodies terhadap antigen plasenta tidak sempurna, yang semakin sempurna pada kehamilan berikutnya. Secara teori, primigravida lebih berisiko untuk mengalami preeklampsia daripada multigravida karena preeklampsia biasanya timbul pada wanita yang pertama kali terpapar vilus korion. Hal ini terjadi karena pada wanita tersebut mekanisme imunologik pembentukan blocking antibody yang dilakukan oleh
HLA-G (Human Leukocyte Antigen G) terhadap antigen plasenta belum terbentuk secara sempurna, sehingga proses implantasi trofoblas ke jaringan desidual ibu menjadi terganggu (Novianti, 2016).

b. Hubungan antara pendidikan dengan kejadian preeklampsia

Tabel 4. Hubungan pendidikan dengan kejadian preeklampsia di RSUD Idaman Banjarbaru Tahun 2017

\begin{tabular}{lcccccc}
\hline \multirow{2}{*}{ Pendidikan } & \multicolumn{2}{c}{ PEB } & \multicolumn{2}{c}{$\begin{array}{c}\text { Tidak } \\
\text { PEB }\end{array}$} & \multicolumn{2}{c}{ Total } \\
\cline { 2 - 7 } & $\mathbf{n}$ & $\%$ & $\mathbf{n}$ & $\%$ & $\mathbf{n}$ & $\%$ \\
\hline Rendah & 44 & 22 & 35 & 17.5 & 79 & 39,5 \\
Sedang & 38 & 19 & 39 & 19.5 & 77 & 38,5 \\
Tinggi & 18 & 9 & 26 & 13 & 44 & 22 \\
\hline & $\mathbf{1 0 0}$ & $\mathbf{5 0}$ & $\mathbf{1 0 0}$ & $\mathbf{5 0}$ & $\mathbf{2 0 0}$ & $\mathbf{1 0 0}$ \\
\hline
\end{tabular}

Tabel 4 menunjukkan bahwa dari 100 orang ibu yang mengalami PEB ada 44 (22\%) yang memiliki pendidikan rendah dan $38(19 \%)$ yang memiliki pendidikan sedang serta $18(9 \%)$ yang memiliki pendidikan tinggi. dari 200 ibu bersalin paling banyak memiliki pendidikan rendah. Berdasarkan perhitungan kolerasi di atas, $\mathrm{N}$ menunjukan jumlah observasi /sampel sebanyak 200 , sedangkan tingginya kolerasi di tunjukan oleh angka 0,110 . Besar kolerasi yang terjadi antara kedua variabel adalah 0,110. Sedangkan angka sig.(2-tailed) adalah 0,121 berarti tidak ada hubungan yang signifikan antara kedua variabel $(0,121>0,05)$.

Penelitian menunjukan tidak ada hubungan maupun kolerasi antara pendidikan ibu dengan kejadian PEB dikarenakan banyak faktor yang 
mempengaruhi kejadian preeklampsi dan hal ini juga dapat dilihat deskriptif bahwa sebagian besar kejadian preeklampsi juga di alami ibu yang memiliki pendidikan sedang dan tinggi.

Teori pendidikan mengatakan bahwa pendidikan adalah suatu kegiatan atau usaha untuk meningkatkan kepribadian, sehingga proses perubahan prilaku menuju kepada kedewasaan dan penyempurnaan kehidupan manusia. Hasil penelitian didapatkan bahwa ibu yang pendidikannnya tinggi maupun berpendidikan rendah memiliki kesempatan yang sama untuk terkena preeklampsia (Dien et al, 2015). Banyaknya pasien yang berpendidikan SMA seiring dengan kesadaran akan pentingnya pendidikan. Pendidikan secara tidak langsung berpengaruh dalam menentukan dan mengambil sebuah keputusan. Tingginya tingkat pendidikan seorang wanita diharapkan semakin meningkat juga pengetahuan dalam mengantisipasi kesulitan kehamilan dan persalinan sehingga termotivasi untuk melakukan pengawasan kehamilan secara teratur. Namun, pendidikan yang dimiliki oleh seseorang belum menjamin untuk menderita atau tidak menderitanya seseorang tersebut pada suatu penyakit tertentu (Kandou et al, 2016).

Hasil penelitian ini sejalan dengan penelitian Rozhikan menunjukkan bahwa tidak ada perbedaan yang bermakna antara ibu hamil yang pendidikannya SD/SMP dengan terjadinya preeklampsia $(p=1,000)$. Dari nilai OR $(95 \% \mathrm{Cl})=1,0(0,56-1,79)$ dapat disimpulkan bahwa ibu hamil yang pendidikannya SD/SLTP mempunyai peluang yang sama untuk terjadinya preeklampsia dibandingkan dengan ibu hamil yang pendidikannya SMA/PT, tetapi hasil penelitian ini tidak sejalan dengan penelitian Nurhusna yang menunjukkan bahwa ada hubungan yang bermakna antara pendidikan dengan kejadian preeklampsia $(\mathrm{OR}=2,3)$. Pendidikan rendah mempunyai risiko terjadinya preklampsia 2-3 kali lebih tinggi dibandingkan dengan pendidikan tinggi (Rozikhan, 2007).

\section{KESIMPULAN DAN SARAN}

Berdasarkan hasil uji statistik dapat disimpulkan bahwa ada hubungan yang signifikan antara paritas dengan kejadian preeklampsia dan tidak ada hubungan yang signifikan antara pendidikan dengan kejadian preeklampsia

Penelitian ini memberikan wawasan tentang penyebab terjadinya preeklampsia pada ibu bersalin yaitu jumlah persalinan yang tidak aman (persalinan 1 atau $>3$ ) yang dapat menjadi faktor resiko terjadinya preeklampsia pada ibu hamil dan bersalin.

\section{DAFTAR PUSTAKA}

Bothamley, Judy dan Maureen Boyle. 2012. Patofisiologi dalam Kebidanan. Jakarta: EGC

Dien Gusta Anggraini Nursal , Pratiwi Tamela, F. 2015. Faktor risiko kejadian preeklampsia pada ibu hamil di rsup $d r$. m. djamil padang tahun 2014, 2014, 38-44. 
Dinas Kesehatan Provinsi Kalsel. 2016. Profil Kesehatan Provinsi Kalimantan Selatan Tahun 2016. Banjarmasin

Ditjen Bina Gizi dan KIA Kemenkes RI. 2013. Upaya percepatan penurunan angka kematian ibu di Indonesia. Downloud on, June, 09, 2014

Kandou, P. R. D., Hutabarat, R. A., Suparman, E., Wagey, F., 2016. Karakteristik pasien dengan preeklampsia Kandidat Skripsi Fakultas Kedokteran Universitas Sam Ratulangi Manado World Health Organization

Lindheimer M.D, Robert J.M, Cunningham F.G, 2009. Chesley's hypertensive disorders in pregnancy, Third Edition. Elseiver Inc. All rights Reserved.p: 87103

Lockwood, C.J., Paidas, M.J. 2000. Preeclampsia and Hypertensive Disorders. In: Complication of Pregnancy fifth ed. Baltimore: Lippincott Wiliams and Wilkins. P. 214-215.

Maryunani, Anik dan Yulianingsih. 2011. Asuhan Kegawatdaruratan Dalam Kebidanan. Jakarta: CV Trans Info Media.

Novianti, H. 2016. Pengaruh Usia Dan Paritas Terhadap Kejadian Pre Eklampsia Di RSUD Sidoarjo Abstract:Jurnal IImiah Kesehatan, Vol. 9, No, 25-31.

Pratiwi, I. 2015. Hubungan Paritas Dengan Kejadian Preeklampsia Pada lbu Hamil Di RSUD WONOSARI. Skripsi.

Rozikhan. 2007. Faktor-Faktor Risiko Terjadinya Pre-eklampsia Berat di Rumah Sakit Dr. H. Soewondo Kendal. Tesis. Semarang: Universitas Diponegoro.

Shah, D. A., \& Khalil, R. A. 2015. Bioactive factors in uteroplacental and systemic circulation link placental ischemia to generalized vascular dysfunction in hypertensive pregnancy and preeclampsia. Biochemical Pharmacology, 95(4), 211-226.
Suwanti, Edi Prasetyo Wibowo, \& Nur Aini Safitri. 2012. Hubungan Tekanan Darah Dan Paritas Dengan Kejadian Preklampsia Di Ruang Bersalin RSUP NTB Tahun 2012. Media Bina Ilmiah. Volume 8, No. 1, Februari 2014. ISSN No. 1978-3787. Pp 25-30

WHO. 2011. Recommendations for Prevention and Treatment of Preeclampsia and Eclampsia, WHO Department of Maternaland Child Health, Geneva, Switzerland 